\title{
KONSTRUKSI FILSAFAT SOSIAL AL-MAWARDI
}

\author{
Alfoe Niam Alwie \\ STAI Mathali'ul Falah Kajen Pati \\ an_alwie@yahoo.com
}

\begin{abstract}
Abstrak
Agama diyakini memiliki peran strategis dalam mengembangkan etika sosial, ekonomi dan politik. Dalam konteks ini, Islam tidak hanya dikembangkan di daerah pemikiran spekulatif murni, tetapi juga harus ditempatkan sebagai dasar etika sosial yang digerakkan oleh praksis sosial. Artikel ini membahas pemikiran al-Mawardi tentang filsafat sosial dan teori kontrak sosial. Menurut al-Mawardi manusia adalah makhluk yang paling membutuhkan bantuan pihak lain sehingga interaksi antar mereka menjadi sesuatu yang pasti. Bentuk kontrak sosial yang ditawarkan oleh al-Mawardi adalah kebutuhan manusia untuk membentuk suatu negara. Negara adalah kebutuhan manusia untuk berkumpul dan membangun ikatan antara satu dengan yang lain. Oleh karena itu, pembentukan negara merupakan kontrak sosial atau perjanjian atas dasar sukarela. Keunikan pemikiran al-Mawardi adalah ia menempatkan Allah sebagai poros dalam segenap sirkulasi sosial. Oleh karena itu ia senantiasa menyandarkan segala pemikiran dan beragam konsepsionalnya tentang kehidupan bermasyarakat kepada grand narative Islam itu sendiri yaitu al-Qur'an dan al-Hadits.
\end{abstract}

\section{Abstract}

THE CONSTRUCTION OF SOCIAL PHILOSOPHY OF AL-MAWARDI. Religion is believed to have a strategic role in developing social, economic and political ethics. In this context, Islam is not only developed in the area of pure speculative thought, but it also should be placed as the basis of social ethics driven by social praxis. This article discusses al-Mawardi's thinkings about social philosophy and the theory of the social contract. According to al-Mawardi, humans are mostly in need of assistance from other parties that the interactions between them become something definite. The form of social contract offered by al-Mawardi is a human 
need to establish a state. State is a human need to gather and build a bond with each other. Therefore, the establishment of the state is a social contract or agreement on a voluntary basis. The uniqueness of alMawardi's thoughts is that he puts God as a pivot in all social circulation. Therefore he always leaned all the thinkings and the diversity of his social life conceptions to the grand narative of Islam that is the al-Quran and al-Hadith.

Kata Kunci: al-mawardi; filsafat sosial; negara.

\section{A. Pendahuluan}

Secara alamiah manusia terlahir dalam keadaan bebas dan merdeka, namun pada kenyataannya ia terkungkung dan terbelenggu oleh realitas sosial politik (conditio sine qua non) ${ }^{1}$. Dengan demikian setiap insan di dunia hidup dalam jaringan sosial politik yang dinamakan negara. Seorang individu tidak bisa sama sekali melepaskan diri dari status sosial maupun politiknya dimana ia dilahirkan.

Dalam konteks sejarah sosial, masyarakat dibentuk, dan membentuk dengan sendirinya, dengan tujuan untuk saling menguatkan dan mewujudkan sebuah komunitas yang tertib dan permanen. Pada hakikatnya manusia adalah makhluk sosial yang memerlukan sikap kebersamaan dengan manusia lainnya untuk mempertahankan dirinya. Sikap berkelompok tersebut menurut Thomas Aquinas memang bersumber dari Tuhan, itulah sebabnya manusia disebut sebagai makhluk sosial. ${ }^{2}$

Interaksi sosial terbangun secara genetis dan geografis hingga muncul sebuah kesadaran bersama akan pentingnya suatu ikatan sosial guna mengatur berbagai persoalan yang timbul di tengahtengah interaksi tersebut. Dengan demikian, dalam masyarakat terkandung makna komunitas, sistem organisasi, peradaban dan interaksi sosial yang dalam sosiologi merupakan inti dari suatu komunitas masyarakat. ${ }^{3}$

${ }^{1}$ Ito Prajna Nugroho. Dilema Negara-Bangsa dalam Perspektif Hannah Arendt (Jakarta: Jurnal Filsafat Driyarkara, edisi Th. XXVI, No. 1, 2002), h. 96.

${ }^{2}$ Muhammad Azhar, Filsafat Politik, Perbandingan antara Islam dan Barat (Jakarta: Rajawali Pers, 1997), h. 32.

${ }^{3}$ Nanih Machendrawaty dan Agus Ahmad Safe'i, Pengembangan Masyarakat Islam, Dari Ideologi, Strategi sampai Tradisi, (Bandung: Rosda, 2001), h. 5. 
Sudah menjadi watak manusia di antara mereka saling berebut dalam pemenuhan kebutuhan karena permusuhan dan kezaliman merupakan watak hewani yang dimiliki manusia. Tidaklah mungkin manusia melakukan aktivitas seorang diri, demikian pula setiap orang membutuhkan bantuan orang lain. Karena proses mempertahankan hidup tersebut, manusia memerlukan kerjasama dalam rangka menjaga eksistensinya, maka negara menjadi suatu keharusan bagi manusia (al-ijtim $\bar{a}$, ḍarūriyyūn li al-insāni) tanpa adanya negara eksistensi manusia tidak akan sempurna. Dengan sendirinya orang yang melaksanakan kewibawaan itu harus menguasai mereka dan memiliki kekuatan melebihi mereka untuk mengatur pelaksanaan kesepakatan bersama, inilah yang dinamakan "kekuatan/otoritas" (Mulk) atau kedaulatan. ${ }^{4}$

Diskursus tentang negara sebagai produk sosialitas manusia tidak pernah akan usang. Selama masih ada kehidupan, maka keberadaan dan eksistensi negara akan tetap dibahas dan diperdebatkan, apalagi di zaman mutakhir seperti sekarang ini. Alasannya sangat jelas dan sederhana, tidak ada seorang pun di dunia ini yang terbebas dari jari-jemari kekuasaan negara (state). Lebih-lebih di negara dunia ketiga, dapat dirasakan langsung betapa wilayah kekuasaan itu sedemikian menyeluruhnya. Negara seakan menjadi pameran sifat kemahakuasaan Tuhan sebagai al-Muhịt, Zat yang maha meliputi. ${ }^{5}$

Dalam pandangan Locke, keadaan pra-negara atau keadaan alamiah bukan seperti yang dilihat oleh Hobbes sebagai kaeadaan perang antar sesama, tetapi suatu masyarakat yang diatur oleh hukum kodrat. Dalam hal ini ada transformasi "keadaan alamiah" (status naturalis) kepada "masyarakat alamiah" (societas naturalis). ${ }^{6}$ Locke sebagaimana Hobbes, berpendapat bahwa pembentukan masyarakat politikataunegara didahuluioleh suatu keadaan alamiah

${ }^{4}$ Ibnu Khaldūn, Muqaddimah, alih bahasa Ahmadie Toha (Jakarta: Pustaka Firdaus, 2000), h. 72-74

${ }^{5}$ Abdel Wahab El-Affendi, Masyarakat Tak bernegara, Kritik Teori Politik Islam, alih bahasa Amiruddin Ar-Rani (Yogyakarta: LkiS, 2000), h. V.

${ }^{6}$ John Locke, Kuasa itu Milik Rakyat, Essai Mengenai Asal Mula Sesungguhnya, Ruang Lingkup dan Maksud Tujuan Pemerintahan Sipil. Alih bahasa A. Widyamartaya (Yogyakarta: Kanisius, 2002), h. 9. 
ketika individu memiliki hak-hak azasi atau kodrati. Bertolak dari teori-teori kodrat manusia tersebut, Hobbes beranggapan bahwa negara yang kuat dan berkekuasaan mutlak itu perlu.

Terbentuknya suatu otoritas sosial-politik atas kesepakatan bersama yang sering disebut negara didahului oleh keberadaan individu yang memiliki hak-hak kodrati. Keadaan ini oleh Locke disebut keadaan ilmiah (state of nature). ${ }^{7}$ Keadaan ilmiah ini adalah adalah keadaan kebebasan (state of license). Individu terikat oleh kewajiban kepada Tuhan dan diatur oleh "hukum kodrat" (law of nature) yang menentukan prinsip-prinsip dasar moralitas: individu tidak boleh mengakhiri hidupnya sendiri; individu harus saling memelihara dan tidak boleh melanggar kebebasan orang lain.

Dalam konstalasi alam pikiran di atas, sebagai pemikir Islam yang hidup pada abad XI M, al-Mawardi mencoba merumuskan suatu konsep filsafat sosial dan teori kontrak sosial. Menurut al-Mawardi manusia adalah makhluk yang paling memerlukan bantuan pihak lain dibandingkan dengan makhluk lainnya. Banyak binatang yang mampu hidup mandiri lepas dari binatang sejenisnya, sedangkan manusia selalu memerlukan manusia lain, dan interaksinya merupakan sesuatu yang tetap dan permanen. Bentuk kontrak sosial yang ditawarkan oleh al-Mawardi adalah kebutuhan manusia untuk mendirikan suatu negara. Negara merupakan hajat manusia untuk memenuhi kebutuhan bersama dan membangun ikatan antara satu dengan yang lainnya. Dengan demikian adanya negara adalah melalui kontrak sosial atau perjanjian atas dasar sukarela. ${ }^{8}$

Tulisan ini secara singkat membahas pemikiran al-Mawardi tentangfilsafatsosialdalamhubungannya dengan sistem kenegaraan. Filsafat sosial adalah upaya yang dilakukan oleh seorang pemikir secara filosofis sebagai usaha untuk mencari pola-pola atau pokok dasar yang mempengaruhi persoalan-persoalan perkembangan masyarakat dalam rangka mencari "worldview" tentang bentuk dan sistem sosial yang paling ideal.

${ }^{7}$ Ibid., h. 11.

${ }^{8}$ Muhammad Azhar, Filsafat Politik.....h. 32 


\section{B. Filsafat Sosial al-Mawardi}

\section{Dimensi Sosialitas Manusia Menurut al-Mawardi}

Menurut al-Mawardi, keadaan masyarakat sebelum terbentuknya sebuah negara berada dalam situasi chaos, maka untuk membangun ketertiban sosial dan menghindari chaos diperlukan suatu perangkat sosial yang dapat mengatur masyarakat untuk menghindari kekacauan tersebut. ${ }^{9}$ Langkah awal yang perlu dilakukan adalah membentuk sebuah komunitas yang tertib berdasarkan kontrak sosial dan kontrak sosial tersebut dapat dilakukan dengan mengangkat seseorang pemimpin negara.

Dalam kitabnya Adāb ad-Dunya wa ad-Dīn lebih jauh alMawardi menegaskan bahwa secara sosiologis dan praktis untuk mewujudkan kehidupan yang teratur dan selaras serta terhindar dari kezaliman dan saling bermusuhan diperlukan adanya suatu kekuasaan yang memaksa dan mengikat, karena menurutnya manusia cenderung memiliki watak bersaing dan saling menyikut dalam memenuhi kebutuhan-kebutuhan mereka. Untuk mengatasi keadaan ini diperlukan sebuah otoritas yang mampu mencegahnya, yaitu akal, agama dan kekuasaan, namun yang terakhir inilah yang paling efektif dan berhasil. ${ }^{10}$ Sedangkan secara praktis menurut alMawardi agama sebagai kebutuhan sosial dan psikologis mempunyai fungsi kontrol dan kekuatan penjaga serta pemeliharaan yang dapat menghindarkan diri dari perbuatan-perbuatan yang bersifat a-sosial dan merusak (destruktif).

a. Relasi Antar Manusia

Meskipun al-Mawardi juga berpendapat bahwa manusia itu makhluk sosial sebagaimana Plato dan Aristoteles, namun ia memasukkan unsur agama dalam teorinya. Baginya manusia adalah makhluk yang paling memerlukan bantuan pihak lain dibanding dengan makhluk lainnya. ${ }^{11}$ Dalam bukunya Adāb ad-Dunya Wa ad-Dīn al-Mawardi menyatakan:

Allah Subhạanahu wa Ta'à'lā Maha Kuasa dan Maha Bijaksana, yang telah menciptakan makhluk-Nya berdasarkan aturan-Nya

${ }^{9}$ al-Mawardi, al-Ahkām As-Sulțāniyyah, Prinsip-prinsip Penyelenggaraan Negara Islam. Alih bahasa Fadhli Bahri, (Jakarta: Darul Falah, 2000), h.1.

${ }^{10}$ Ibid, h. 194-196.

${ }^{11}$ Muhammad Azhar, Filsafat Politik.......... h. 81. 
dan mengadakannya menurut ketentuan-Nya. Di antara hal yang diciptakan berdasarkan aturan dan ketentuan-Nya bahwa Dia (Allah) telah menciptakan manusia sebagai makhluk yang saling membutuhkan satu sama lainnya dan menjadikannya sebagai makhluk yang lemah, supaya satu sama lain saling memerlukan. ${ }^{12}$

Dalam konsep Islam, manusia minimal menyandang dua status pokok; yang pertama bersifat horizontal (hablum min an-nās), yaitu manusia diciptakan oleh Allah sebagai khaliffatullāh ${ }^{13}$ (wakil Allah) di muka bumi ini, yang mempunyai sekian tanggung jawab; menjaga ketertiban sosial dan menciptakan kehidupan yang baik dan damai. Sebagai khalifah, atau sebagai wakil Tuhan di bumi manusia berpotensi dan memiliki kekuatan untuk mengatur dan menata segala kehidupan yang bersifat duniawiah. Sebab tugas utama dari khalifah adalah untuk memberi kesejahteraan bagi umat manusia seluruhnya.

Sedangkan yang kedua bersifat vertikal (hablum minallāh), manusia sebagai hamba Allah ('abd Allāh) memiliki tanggung jawab menyembah sang Khaliq sebagai Dzat yang maha tinggi dan sumber segala sesuatu berasal. Dalam posisi ini manusia mempunyai kewajiban mengakui keberadaan dirinya sebagai makhluk yang lemah dan bergantung pada kekuatan lain. Kalau pada posisi yang pertama dia diberikan keleluasaan untuk berekspresi dan mengatur segala kebutuhan yang menyangkut persoalan dunia, "antum a'lamu bi umūri dunyākum", maka sebagai 'abd Allāh ia wajib untuk mengabdi dan melaksanakan segala perintah Allah dan menjauhi setiap larangan-Nya. Ritualitas penyembahan terhadap Allah ini merupakan media untuk membersihkan diri dari pergolakan sosial yang terkadang menceburkan manusia pada perbuatan-perbuatan tidak terpuji.

Eksistensi manusia sebagai makhluk yang saling membutuhkan satu dengan lainnya merupakan kodrat alam (intervensi kekuasaan Allah) secara niscaya. Manusia diciptakan

${ }^{12}$ al-Mawardi, Kenikmatan Kehidupan Dunia dan Agama; Etika dalam Pergaulan, terj. Kamaluddin Sa'diyatul haramin (Jakarta: Pustaka Azzam, 2001), h. 186.

${ }^{13}$ Al-Qur'an dan Terjemahannya (Jakarta: Mujamma' Al Mālik Fath Li țiba'at Al-Mușḥaf Asy-Syarif Medinah Munawwarah. P.O.BOX. 6262 Kerajaan Saudi Arabia, 1415 H), h. 13, 601. 
tidak dalam kondisi sempurna yang tidak membutuhkan pihak manapun, namun sebaliknya manusia sengaja diciptakan dalam keadaan lemah supaya satu sama lain saling membutuhkan dan melengkapi, bekerja sama. Untuk itu semua memiliki kemampuan yang berbeda-beda sehingga dengan perbedaan itu mereka saling membantu untuk mencapai suatu kesempurnaan.

Dalam relasi sosial, manusia sebagai makhluk yang mempunyai daya cipta dan karsa yang tinggi dan penuh ambisi sudah barang tentu akan melakukan setiap upaya untuk mewujudkan ambisi dan cita-citanya. Karena dengan segenap kemampuan dan potensinya manusia mampu untuk melakukan segala keinginannya. Dalam proses pemenuhan ambisi dan citacitanya inilah seringkali menimbulkan persoalan sosial meskipun pada dasarnya tidak seorangpun diantara kita ingin menjadi orang yang cacat sosial, namun kadangkala karena faktor katerpaksaan dan sulitnya mencari jalan lain manusia menjadi jahat dan culas.

Perbedaan bagi al-Mawardi merupakan sebuah keniscayaan, karena dengan perbedaan relasi dan komunikasi sosial akan terjalin, karena tidaklah mungkin seorang manusia hidup dengan dirinya sendiri tanpa membutuhkan bantuan orang lain. Kaeadaan alamiah itulah yang mendorong manusia membentuk sebuah sistem dan jalinan sosial. Perbedaan dalam hal ini menjadi potensi bagi manusia untuk mewujudkan sebuah tatanan kehidupan sosial secara bersama. Meskipun di satu sisi dalam waktu serta situasi tertentu, masyarakat dalam dirinya tetap menyimpan suatu potensi konflik dan perbedaan. ${ }^{14}$

Terjadinya pertentangan atau pertikaian, pada wilayah tertentu akan mendorong manusia melakukan koalisi atau persekongkolan yang kemudian disebut jiwa persahabatan yang akan terjadi di antara mereka. Pertentangan ini akan mempunyai berbagai fungsi yang di dalamnya termasuk tujuan naluriah manusia itu sendiri yaitu dalam rangka mempertahankan diri, baik dari pengaruh alam maupun siklus kejahatan yang ditimbulkan oleh manusia lainnya.

Adapun perbedaan yang secara determinan ada pada manusia akan meletakkan manusia dalam suatu kondisi dimana di antara

${ }^{14}$ Ibid., h. 191. 
mereka saling membutuhkan dan tolong-menolong atau kerja sama saling menguntungkan (simbiosis mutualism), dan ini merupakan hal yang asasi bagi manusia karena pada dasarnya ia adalah makhluk sosial yang sangat tergantung dengan pihak lain.

b. Relasi Manusia dengan Lingkungan dan Tuhan

Pada posisinya yang lain, manusia sebagai 'abd Allāh. Ia memiliki makna dan arti yang sangat dalam. Manusia adalah hamba yang berkewajiban untuk senantiasa mengabdi dan selaras dengan realitas tertinggi yang Maha Suci. Hal ini mengabadikan manusia ke dalam suatu tuntutan hidup yang berkualitas baik terhadap dirinya, lingkungannya maupun secara metafisik bertanggung jawab kepada Tuhannya, yaitu Allah. Dalam hal ini al-Mawardi berpendapat di bukunya Adāb ad-Dunyā Wa ad-Dīn:

Katahuilah bahwa sesungguhnya Allah Subhānahu wa Ta'āla mengharuskan makhluk-Nya agar menjadi hamba yang taat kepadaNya, mewajibkan bagi mereka hukum-hukumNya dan mengutus kepada mereka para rasul-Nya serta mensyariatkan bagi mereka agama-Nya, bukan untuk tujuan memberi mereka beban ataupun untuk kepentingan ibadah kepada-Nya manum ditujukan untuk kepentingan mereka sendiri sebagai penghormatan dari-Nya bagi mereka sebagaimana Dia memuliakan mereka dengan nikmatnya yang tak terhingga. ${ }^{15}$

Walaupun selain manusia, Allah juga menciptakan berbagai makhluk, akan tetapi pada manusia diberikan suatu potensi yang luar biasa, yang mengatasi seluruh makhluk lainnya. Keluarbiasaan karunia tersebut terletak pada akal budi manusia. Dengan akal budi, manusia mempunyai kesadaran dan kemampuan berfikir untuk membedakan mana yang baik dan buruk. Ini adalah kelebihan yang sengaja diberikan oleh Sang pencipta kepada manusia, sehingga dengan potensinya tersebut, manusia diwajibkan untuk menjaga dan melestarikan kehidupan dunia ini dengan sebaik-baiknya. ${ }^{16}$

Dalam konteksnya dengan alam, manusia memiliki keharusan kosmologis, yaitu realitas alam dengan sengaja digatungkan kepada manusia itu sendiri. Tanggung jawab kosmis ini adalah suatu

${ }^{15}$ al-Mawardi, Kenikmatan..., h. 132.

${ }^{16}$ al-Qur'an dan Terjemahannya, op.cit., h. 822. 
tanggung jawab yang akan membawa kepada kebahagiaan manusia tersebut. Sebab selain berkewajiban melestarikan, manusia juga akan menjadi pengguna utama dari keberadaan alam tersebut. Menggunakan sebanyak-banyaknya dan menjaga kelestariannya sebaik mungkin pada dasarnya merupakan kepentingan manusia itu sendiri. ${ }^{17}$

Pada tingkat relasi antara manusia, alam dan Tuhan, manusia mengandaikan suatu kepentingan politis tertentu, yaitu dalam rangka mencapai kebahagiaan abadi dalam dirinya. Di sini diketahui bahwa alam dan Tuhan tidak memiliki kepentingan individual bagi dirinya, jadi hanya manusialah yang vested interest.

Sesuatu yang menjadi maksud alamiah manusia -dalam hubungan dengan Allah dan alam- ialah mencapai suatu kabahagiaan yang sempurna. Kebahagiaan jasmani dan rohani yang berlangsung dari dunia sampai di akhirat nanti.

Oleh sebab itu Allah menyediakan keharusan yang lain yaitu 'ibādah. Ibadah merupakan perintah Tuhan yang baik untuk manusia, karena dengan ibadah yang menjadi tempat atau waktu menusia berkomunikasi dengan sang Penciptanya juga sebagai media untuk merefleksikan kembali segala kegemuruhan problem sosial yang dihadapi seseorang manusia. Ibadah merupakan taman firdaus dimana tempat orang-orang mandi dan melepaskan segala kotoran, kotoran pikiran maupun kotoran perbuatan dan tingkah laku sosial.

2. Kedudukan dan Peran Agama dalam Filsafat Sosial al-Mawardi

Al-Mawardi adalah seorang ulama dan pemikir yang taat beragama. Ia senantiasa menyandarkan segala pemikiran dan beragam konsepsionalnya tentang kehidupan bermasyarakat kepada grand naratiive Islam itu sendiri yaitu al-Qur'an dan al-Hadis. Dan keduanya merupakan sesuatu yang tidak dapat dimengerti tanpa adanya akal yang mampu menjelaskan menguraikan apa yang tersirat di dalamnya.

Dengan demikian agama -menurut al-Mawardi- menjadi inspirator utama bagi manusia dan menjadi penuntun bagi jalannya manusia dalam menempuh kehidupan yang sebenarnya. Agama

${ }^{17}$ Ibid, h. 816 . 
akan memberi jalan yang terang baik dalam bertindak maupun dalam berfikir, karena dalam agama terdapat petunjuk-petunjuk Allah yang banyak tidak terfikirkan atau tidak mampu dipikirkan oleh manusia yang kapasitasnya tidak mungkin semutlak Tuhan, ia adalah makhluk dengan segala keterbatasannya.

a. Akal dan Nafsu bagi Manusia

Sebagaimana disinggung dalam definisi filsafat sosial, bahwa dalam proses terbentuknya suatu komunitas sosial tidak luput dari perkembangan dinamika perilaku internal dari komunitas tersebut. Dinamika ini sudah barang tentu akan sangat dipengaruhi oleh pola pikir dan nalar komunitas itu dalam berproses, di sinilah signifikasi akal dan nafsu manusia dapat ditemukan, karena dengan dinamikanya, jenis dan tipe sebuah masyarakat akan dibentuk.

Al-Mawardi menyebut akal sebagai landasan bagi orang yang beragama dan merupakan sumber dari seluruh tatanan dunia. Segala konstruksi sosial yang dibentuk oleh manusia untuk mencapai suatu moralitas bersama pada dasarnya dibangun di atas landasan akal budi itu sendiri. al-Mawardi mengatakan bahwa asas keutamaan dan sumber etika adalah akal fikiran.

Justifikasi Allah kepada akal tersebut dapat kita lihat pada bentuk hukum yang ditujukan kepada manusia. Ada hukum yang wajib menurut akal dengan diperkuat oleh syari’at dan ada hukum yang dibolehkan oleh akal akan tetapi wajib menurut syarīat. Ini membuktikan bahwa akal dijadikan tolok ukur atau barometer bagi pelaksanaan dan proses interaksi sosial yang hendak dijalani manusia. ${ }^{18}$ Akal merupakan suatu substansi yang paling halus dalam struktur tubuh manusia dan bersifat ruhani yang dengan akal ini pula manusia dapat mencapai kesempurnaan. Dalam akallah bersumber segala pengetahuan manusia dan juga menjadi tempat mengendapnya semua pengetahuan yang datang dari luar diri manusia. Akal adalah cahaya yang dapat membedakan antara yang hak dan yang batil.

Akal mengandung kecerdasan dan kejeniusan yang luar biasa bagi para pemiliknya yang akan membawa kepada suatu penciptaan relasi sosial yang berguna. Karena akal pulalah suatu

${ }^{18}$ al-Mawardi, al-Ahkam ......, h. 40. 
kontrak dan kontrol masyarakat dapat diabadikan ke dalam bentukbentuk kesepakatan antar individu dalam masyarakat tersebut.

Sementara itu, nafsu merupakan kekuatan yang berlawanan dengan akal itu sendiri, dan ketika hawa nafsu berkuasa maka dia akan membawa kepada kehancuran. Kekuatan nafsu ini sangat eksklusif dan begitu berkuasa. Kekuasaan nafsu itu akan semakin mendapatkan tempatnya manakala ia senantiasa dituruti. Pemberian tempat yang leluasa kepada nafsu ini pada bagian tertentu akan membubuh akal itu sendiri dan paling tidak ia akan terus mendominasi, maka pada skala inilah manusia akan jatuh pada perbuatan yang buruk dan jahat.

b. Etika Sosial Keagamaan dalam Konstruksi Masyarakat

Hidup bersama dalam suatu lingkungan sosial-sebagaimana tuntutan dasar manusia- memerlukan kesepakatan-kesepakatan bersama demi kelangsungan kebersamaan itu sendiri. Allah dengan atau melalui agama telah memberikan aturan-aturan kepada manusia bagaimana seharusnya bertindak yang baik.

Karakteristik baik dalam perilaku bermasyarakat tersebut dapat dilihat dari dua sisi, yaitu teraturnya segala urusan dan adanya suatu pegangan yang dapat memperbaiki perilaku penghuninya. ${ }^{19}$ Dengan demikian diperlukan suatu aturan main yang disepakati bersama dalam masyarakat untuk kebaikan bersama di mana di dalamnya mengandung suatu keseimbangan moral antara hidup keduniaan dan di akhirat nanti. Dan itu membutuhkan seorang panutan yang bisa memberi peringatan terhadap kebaikan.

Seorang panutan atau imam dibutuhkan dalam rangka memantau dan menjaga orang yang selalu taat melaksanakan kebaikan dan menghindari keburukan, mengarahkan orang yang berbuat kebejatan dan menghindari taat, serta membina orang yang selalu taat peraturan dan sekaligus melaksanakan kejahatan. Ini merupakan komponen penting dalam membangun suatu etika bermasyarakat yang baik, sebab jika tiga kepribadian manusia itu tidak dilokalisir akan terjadi benturan dalam masyarakat yang cenderung merusak perdamaian.

Untuk mencapai suatu bangunan masyarakat yang baik

${ }^{19}$ Ibid., h. 190. 
dalam kehidupan nyata menurut al-Mawardi minimal ada enam faktor untuk mewujudkan ketertiban sosial, yaitu; Pertama adalah Agama yang ditaati. Agama merupakan faktor yang sangat kuat yang adapat memperbaiki dunia dan suatu keyakinan yang dapat mengarahkan manusia pada suatu keseimbangan hidup antara dunia dan akhirat, ia juga berfungsi sebagai pengendali dari kesemrawutan perbuatan manusia itu sendiri. Kedua, adalah pemerintahan yang kuat dan berwibawa. Dengan kekuasaan yang dimiliki oleh negara atau pemerintah, ia akan dapat memaksa manusia untuk tunduk terhadap kesepakatan bersama atau hukum bersama demi kelangsungan hidup bersama pula. Ketiga, adanya keadilan yang merata. Keadilan yang nerata akan mendorong individu-individu untuk bersatu dan taat serta secara bersama menciptakan kemakmuran, kesejakteraan ekonomi dan kedamaian diantara para penduduknya. Keempat, keamanan yang menyeluruh, yang meliputi adanya perlindungan lahir dan batin bagi keseluruhan umat manusia. Kelima, negeri yang subur. Pemenuhan kebutuhan dasar manusia yang berupa makan merupakan hal terpenting. Oleh karena itu kesuburan suatu negri juga menjadi faktor utama untuk terciptanya perdamaian, mencegah perampokan dan kejahatan lainnya. Keenam, cita-cita yang tinggi atau luhur. Cita-cita akan memberikan spirit tersendiri bagi manusia untuk melakukan perjuangan meraih sesuatu. Sebab nikmatnya dunia adalah terletak pada proses perjuangan itu sendiri. ${ }^{20}$

Dengan demikian kerukunan umat manusia dalam interaksi sosialnya dapat tercipta manakala menjadikan agama sebagai moralitas tertinggi dalam menata inspirasi, kehendak-kehendak sosial yang ideal dan cita-cita yang diinginkan.

\section{Konstruksi Filsafat Sosial al-Mawardi}

Al-Mawardi mengandalkan filsafat sosialnya pada apa yang disebut negara dan masyarakat. Bagaimana suatu tatanan tersebut terbentuk dan bagaimana seharusnya terlaksana. al-Mawardi meyakini bahwa pesoalan keduniaan merupakan fitrah yang harus dihadapi dengan seksama oleh manusia dengan landasan yang berkeseimbangan antara dunia dan akhirat.

${ }^{20}$ Ibid., h. 193-208. 
Turunnya manusia di bumi telah membawa naluri berteman dengan sesamanya. Sehingga pada perkembangan berikutnya muncul kehendak berserikat dalam rangka mencapai etik sosial yang diinginkan bersama. Atas dasar inilah al-Mawardi menyatakan bahwa secara mendasar manusia itu adalah makhluk yang bisa menyatakan keberadaanya dengan adanya manusia yang lain.

Dalam konteks perubahan perkembangan sosial kemasyatakatan ini al-Mawardi memilih jalur teori evolusi dan menolak bahwa perubahan dan perkembangannya dilakukan secara revolusioner. Hal itu terlihat bahwa dalam kekacauan politik - di mana ia tinggal semasa hidupnya - yang terjadi harus disikapi secara bijaksana. Ia juga memilih tunduk kepada wacana agama yang mengajurkan untuk memperkecil kemudlaratan ketimbang melawan dengan kemudlaratan pula sehingga menimbulkan semakin parahnya keadaan. ${ }^{21}$

Pada situasi alam yang demikian itu ia merasa dituntut untuk mengkonsepsi bagaimana suatu etika bermasyarakat dan bagaimana transisi kepemimpinan mesti berlangsung. Sistem feodalisme yang berlangsung semasa hidupnya, ketika kaum muslim yang lemah dijadikan alas kaki serta mengalami penindasan yang dahsyat semakin membulatkan tekadnya untuk mengingatkan penguasa dan masyarakatnya dengan nilai-nilai filsafat yang ia introdusir dari Islam. Lebih jauh ia menguraikan gagasan tersebut dalam bahasan berikut.

\section{Negara sebagai Wujud Kontrak Sosial}

Menurut al-Mawardi interaksi sosial manusia bersifat langgeng dan permanen, manusia diciptakan Allah sebagai makhluk yang lemah, karenanya mausia dibekali potensi intelektual yang akan menuntunnya berperilaku tertentu dan yang akan membimbingnya menuju kebahagian dunia akhirat. Perbedaan intelegensi, intelektual, kepribadian, bakat antar manusia justru akan mendorong manusia untuk saling bekerjasama. Berangkat dari sinilah manusia akhirnya sepakat untuk membentuk sebuah

${ }^{21}$ Asghar Ali Engineer, Islam dan Teologi Pembebasan, (Yogyakarta: Pustaka Pelajar, 1999), h. 227. 
komunitas guna menjaga setiap kepentingan dan kebutuhannya melalui kontrak sosial yang berbentuk negara. ${ }^{22}$

Kebutuhan dasar untuk berserikat dan membentuk suatu kelompok bagi manusia merupakan gejala alamiah dalam struktur kosmologi makro, dan itu terjadi secara spontan. Spontanitas yang berkembang tersebut berawal dari suatu tuntutan untuk memenuhi segala kebutuhan hidup baik berupa makanan ataupun kemanan. Kemudian pada tingkat menjaga kepentingan masing-masing inilah manusia akhirnya harus menjatuhkan pilihannya untuk membuat kesepakatan-kesepakatan bersama.

Kesepakatan atau kontrak itu dipaksa untuk terbentuk oleh suatu keadaan yang barbarian, yang mana pada masa Hobbes misalnya, dikenal istilah "peperangan segala lawan segala". ${ }^{23}$ Kepentingan suatu entitas masyarakat pada gilirannya akan berdiri berhadapan dengan kepentingan entitas lainnya, dan itu akan terus berlangsung sepanjang sejarah.

Berangkat dari fenomena ini maka masyarakat harus membentuk kontrak dan kesepakatan, baik di antara mereka dalam satu jalan maupun dengan mereka yang berada di pihak lain. Sampai di sini, kesepakatan yang terjadi masih bersifat lokal, kepada kelompok-kelompok berdasar etnis dan keturunan tertentu. Dan ini masih menyisakan potensi perang antar etnis. Oleh karena itu beberapa kelompok ini harus membuat suatu kontrak yang lain dan berstatus lebih luas. Mereka harus pula menentukan dan memilih panutan yang nantinya akan disepakati bersama. Kemudian kontrak itu dapat dilaksankan oleh individu dengan panutan (Penguasa) sebagaimana Rosseau, atau dapat saja dilakukan oleh rakyat secara keseluruhan dengan pihak penguasa atau penutan, demikian Hobbes. ${ }^{24}$

Sedikit berbeda dari konsepsi yang di atas adalah apa yang diajukan oleh al-Mawardi, bahwa Allah menjadi poros utama dari segenap sirkulasi sosial adalah suatu keniscayaan. Allah sengaja menciptakan manusia dalam keadaan lemah secara fisik

${ }^{22}$ Muhammad Azhar, Filsafat Politik...., h. 81.

${ }^{23}$ Jean-Jacques Rosseau, Du Contrat Social: Perihal Kontrak Sosial, terj. Ida Sundari Husen dan Rahayu Hidayat (Jakarta: Dian Rakyat, 1989), h. VI.

${ }^{24}$ Ibid., h. VII. 
dan mengahadirkannya dalam suatu kondisi yang berbeda-beda. Dari kelemahan ini manusia menjadi sosok yang membutuhkan bantuan baik dari Allah maupun manusia lainnya. Kemudian dari perbedaan, manusia terinspirasi untuk saling mengisi kekurangan dan kelebihannya.

Al-Mawardi berpendapat bahwa perbedaan bakat, pembawaan dan kemampuan antara manusialah yang merupakan pendorong bagi mereka untuk saling membantu. Kelemahan manusia yang tidak memiliki kemampuan untuk memenuhi semua kebutuhannya sendiri, dan terdapatnya keanekaragaman dan kecenderungan alami serta kemampuan, semua itu mendorong manusia untuk bersatu dan saling membantu dan akhirnya sepakat untuk mendirikan negara. Dengan demikian menurut al-Mawardi, lahirnya negara adalah hajat umat manusia untuk mencukupi kebutuhan mereka bersama, dan otak merekalah yang mengajari tentang cara bagaimana saling membantu dan tentang bagaimana mengadakan ikatan satu sama lainnya. ${ }^{25}$

Plato, Aristoteles dan al-Mawardi adalah orang-orang yang menyebut manusia sebagai makhluk sosial yang secara otomatis membawa naluri kesosialan dengan segala jenis kebutuhan yang harus dipenuhi. Akan tetapi al-Mawardi tetap berpijak kepada agama sehingga mengatakan bahwa semua yang terjadi pada manusia itu merupakan ciptaan Tuhan. Itulah yang membedakan al-Mawardi dengan para filosof sebelumnya.

Demikianlah sejarah terjadinya kontrak sosial menurut al-Mawardi. Jika menurut pemikir Yunani bahwa kontrak sosial dibentuk oleh suatu lingkungan yang membahayakan akan tetapi bagi al-Mawardi hal itu - kotrak sosial - terjadi karena merupakan hajat manusia itu sendiri yang memang diciptakan untuk bersatu dalam perbedaannya.

Al-Mawardi mendasarkan teori filsafat sosial-politiknya kepada hal-hal yang kongkrit dan langsung bersentuhan dengan kenyataan yang ada. Sebagaimana telah disinggung di atas bahwa al-Mawardi memilih jalan evolusi ketimbang revolusi. Sehingga usulan-usulan yang muncul sebagai respons terhadap kondisi

${ }^{25}$ Munawir Sjadzali, Islam dan Tatanegara (Jakarta: UI Press, 1993), h. 60-61. 
sosial politik yang amburadul pada masanya, ia menggagas wacana reformasi, misalnya penyelesaian konflik tentang pergantian khalifah yang mana terjadi dikotomi antara orang Arab dan non Arab. Dia mengusulkan bahwa jabatan khalifah tetap orang Arab dan sebagai bawahannya yang setingkat menteri dapat diambil dari luar Arab. Mungkin inilah yang belakangan disebut dengan penyelesaian win-win solution.

Di dunia Barat ada tiga pemikir filsafat politik yang juga mengemukakan teori kontrak sosial. Yang antara lain adalah Brutus yang mengatakan bahwa kontrak sosial itu didasarkan pada dua hal: pertama, dibuat antara Tuhan di satu pihak dan raja serta rakyatnya di lain pihak, yang berisikan janji bahwa raja dan rakyatakan tetap patuh kepada perintah-perintah agama. Kedua dibuat antara raja dan rakyat yang berisikan bahwa rakyat berjanji untuk taat dan patuh kepada raja selama pemerintahan raja tersebut dilaksanakan dengan adil.

Selanjutnya pemikir kedua adalah Hobbes, yang mengemukakan bahwa kontrak sosial itu terjalin antara sesama rakyat sendiri, sedangkan raja tidak merupakan bagian dari kontrak sosial tersebut, akan tetapi ia hanyalah produk dari kontrak sesama rakyat. Kemudian pemikir yang ketiga, Locke, memberikan gagasan bahwa kontrak sosial itu melibatkan raja sebagai partner dalam kontrak sosial. Dengan demikian teori kontrak sosial sebagaimana dikemukakan oleh Brutus, terutama teori keduanya, Hobbes dan Locke memiliki kesamaan dengan teori kontrak sosial al-Mawardi. ${ }^{26}$

Lain lagi dengan kontrak sosial yang digagas oleh Rosseau yang sependapat dengan al-Mawardi. Mereka melakukan klasifikasi kontrak sosial tersebut pada dua hal; pertama, kontrak sosial itu terjadi hanya sesama rakyat atau anggota-anggota masyarakat.Kedua, melalui kontrak sosial itu masing-masing individu melimpahkan segala hak perorangan kepada komunitas sebagai satu keutuhan. Dengan demikian segala hak alamiah, termasuk kebebasan penuh untuk berbuat sekehendak hati yang dimiliki oleh orang-orangorang dipindah ke dalam satu komunitas yang dalam hal ini adalah negara yang menurut al-Mawardi dipimpin oleh sorang khalifah.

${ }^{26}$ al-Mawardi, Al-Ahkām....., h. 67-69. 
Oleh karena itu suatu pemerintahan itu merupakan trust atau amanah. Sedangkan rakyat sebagai trustor dan sekaligus beneficiary atau pemberi amanat dan juga melimpahkan kepentingannya kepada raja atau Khalifah sebagai penerima amanah tersebut. Dengan hal itu berarti bahwa Khalifah menyandang beban kewajiban yang harus dilaksanakan, yang juga berarti pula bahwa jabatan itu bukanlah hak akan tetapi kewajiban itu sendiri.

2. Bentuk Kepemimpinan Sosial dan Partisipasi Masyarakat

Al-Mawardi memberikan frame besar dalam bentuk kepemimpinan ini yaitu dengan kategori amamah yang berorientasi kepada penguasaan dua dimensi yakni agama dan politik itu sendiri. Imamah yang dimaksud al-Mawardi adalah Khalifah, raja, sultan atau kepala negara. Ia juga memberikan baju agama kepada jabatan kepala negara di samping baju politik. Menurut al-Mawardi, Allah mengangkat untuk umatnya seorang pemimpin sebagai pengganti kekhalifahan Nabi, untuk mengamankan agama, dengan disertai mandat politik, yang dengan demikian seorang imam di satu pihak adalah seorang pemimpin agama dan pemimpin politik di lain pihak. $^{27}$

Al-Mawardi menyebutkan bahwa sesungguhnya imām atau Khalifah tersebut diproyeksikan untuk mengambil alih peran kenabian dalam menjaga agama dan mengatur dunia. Pemberian jabatan imāmah atau kepemimpinan kepada orang yang mampu menjalankan tugas di atas pada umat adalah suatu keniscayaan. ${ }^{28}$

Menurut al-Mawardi, imāmah menjadi sesuatu yang wajib adanya. Sebab bagi orang yang berakal, biasanya selalu mempunyai kecondongan untuk tanduk kepada imam atau khalifah yang melindungi mereka dari segala bentuk ketidakadilan, memutuskan konflik dan permusuhan yang terjadi di antara mereka. Khalifah berfungsi sebagai lalu lintas masyarakat dalam mengatur persoalan kesehariannya baik dalam hal ekonomi ataupun dalam sistem komunikasi ideal ${ }^{29}$ antar manusia.

${ }^{27}$ Ibid., h. 63 .

${ }^{28} \mathrm{Ibid}, \mathrm{h} .1$.

${ }^{29}$ Komunikasi ideal yang penlis maksudkan adalah sebagaimana dikemukakan oleh Habermas yang berarti bahwa rasionalitas modern dengan segala proses dehumanisasi di dalamnya dapat diatasi dengan membudayakan 
Al-Mawardi juga memberikan justifikasi teologis normatif bagi urgenitas kepemimpinan yang eksistensinya sangat penting dalam hidup bermasyarakat itu sendiri. Landasan tersebut adalah firman Allah yang artinya sebagai berikut:

"Hai orang-orang yang beriman, taatilah Allah dan taatilah Rasul, dan Ulil Amri ( para pemimpin) di antara kalian." (An-Nisa : 59)

Al-Mawardi, meskipun menyandang beberapa predikat ilmuwan yang cerdas yang sejajar dengan para filosof Barat, ia tetap tidak bersedia melepas mainstream agama Islam yang ia yakini. Dalam kaitannya dengan bentuk-bentuk kepemimpinan yang ia gagas tetap mendudukkannya di atas dasar equality atau kesetaraan bagi manusia. Satu kelompok tidak dapat dilebihkan dari kelompok lain selain taqwanya.

Imam tidak mempunyai kelebihan atas orang lain yang ada di wilayah-wilayah. Sehingga dalam pemilihan dan penentuan pemimpin daerah yang paling berhak menentukan adalah mesyarakatnya sendiri yang tentunya lebih paham dengan karakter calon pemimpin serta tahu persis kondisi yang dihadapi masyarakat pada saat itu. Dan jabatan Imam daerah pun lebih utama diberikan kepada orang daerah tersebut.

Pada tingkat ini al-Mawardi telah menyiapkan suatu konstruksi dan sistem pemerintahan modern yang manyiratkan adanya unsur legislasi, yudikasi, dan ekskutif bagi suatu pemerintahan. Kemudian pemberian kesempatan kepada daerah untuk menentukan pilihan sendiri bagi yang akan memimpin mereka merupakan kata lain dari otonomi daerah sebagaimana kita kenal baru mulai digalakkan di Indonesia sekarang ini.

Selain itu al-Mawardi juga menggagas keterlibatan masyarakat dalam proses penentuan imāmah yang akan mereka angkat sebagai panutan. Ia menunjukkan suatu pemilihan (pemilihan umum) dalam penentuan siapa yang paling berhak. Meskipun pada masa itu masih terbatas pada sekelompok kecil yang berhak memilih, akan tetapi ini mengindikasikan suatu sistem demokrasi yang memposisikan kedaulatan rakyat sebagai suatu elemen sangat penting.

suatu komunikasi yang bebas dari polusi kepentingan baik itu berupa kekuasaan atau kepentingan ekonomi dan uang. 
Keterlibatan masyarakat dalam penentuan seorang khalifah ini juga terinspirasi dari wacana musyawarah dalam Islam itu sendiri, yaitu ketika akan menentukan hal-hal yang menyangkut hajat hidup dan kemaslahatan orang banyak harus diputuskan secara bersama pula. Sampai disini didapatkan adanya suatu spirit yang tinggi dan mengandung suatu wawasan pemikiran yang universal dalam filsafat sosial al-Mawardi yang mengkristal dalam filsafat sosial di atas. Di sana juga menyimpan ide-ide universalitas agama yang bergandengan dengan mesra dengan ilmu pengetahuan yang bersumber dari akal budi mausia

\section{Kesimpulan}

\section{Filsafat Sosial al-Mawardi}

Al-Mawardi mengandaikan filsafat sosialnya pada apa yang disebut negara dan masyarakat. Bagaimana suatu tatanan tersebut terbentuk dan bagaimana seharusnya terlaksana. al-Mawardi meyakini bahwa persoalan keduniaan merupakan fitrah yang harus dihadapi dengan seksama oleh manusia dengan landasan yang berkeseimbangan antara dunia dan akhirat.

Kebutuhan dasar untuk berserikat dan membentuk suatu kelompok bagi manusia merupakan gejala alamiah dalam struktur kosmologi makro, dan itu terjadi secara spontan. Spontanitas yang berkembang tersebut berawal dari suatu tuntutan untuk memenuhi segala kebutuhan hidup baik berupa makanan ataupun keamanan. Kemudian pada tingkat menjaga kepentingan masing-masing inilah manusia akhirnya harus menjatuhkan pilihannya untuk membuat kesepakatan-kesepakatan bersama.

Sedikit berbeda dari konsepsi yang digagas oleh para filosof Barat al-Mawardi berpendapat bahwa keberadaan Allah menjadi poros utama dari segenap sirkulasi sosial adalah suatu keniscayaan. Allah sengaja menciptakan manusia dalam keadaan lemah secara fisik dan menghadirkan dalam suatu kondisi yang berbeda-beda. Dari kelemahan ini manusia menjadi sosok yang membutuhkan bantuan baik dari Allah maupun manusia lainnya. Kemudian dari perbedaan, manusia terinspirasi untuk saling mengisi kekurangan dan kelebihannya. 
Perbedaan bakat, pembawaan dan kemampuan antara manusialah yang merupakan pendorong bagi mereka untuk saling membantu. Kelemahan manusia yang tidak memiliki kemampuan untuk memenuhi semua kebutuhannya sendiri, dan terdapatnya keanekaragaman dan kecenderungan alami serta kemampuan, semua itu mendorong manusia untuk bersatu dan saling membantu dan akhirnya sepakat untuk mendirikan negara. Dengan demikian menurut al-Mawardi, lahirnya negara adalah hajat manusia untuk mencukupi kebutuhan mereka bersama, dan otak merekalah yang mengajari tentang cara bagaimana saling membantu dan tentang bagaimana mengadakan ikatan satu sama lainnya melalui kontrak sosial.

2. Peran dan Fungsi Agama dalam Konstruksi Sosial Masyarakat

Al-Mawardi adalah seorang ulama dan pemikir yang taat beragama. Ia senantiasa menyandarkan segala pemikiran dan beragam konsepsionalnya tentang kehidupan bermasyarakat kepada grand narative Islam itu sendiri yaitu al-Qur'an dan al-Hadits. Dengan demikian agama -menurut al-Mawardi- sudah seharusnya mejadi inspirator utama bagi manusia dan menjadi panutan bagi jalannya manusia dalam menempuh kehidupan yang sebenarnya. Agama akan memeri jalan yang terang baik dalam bertindak maupun dalam berfikir, karena dalam agama terdapat petunjuk-petunjuk Allah yang banyak tidak terfikirkan atau tidak mampu difikirkan oleh manusia yang kapasitasnya tidak mungkin semutlak Tuhan, ia adalah makhluk dengan segala keterbatasannya.

Demikian halnya dalam proses pembentukan masyarakat yang tenteram adil dan makmur, agama Islam dengan segenap ajaran dan nilai-nilai universalnya, menempati peran yang strategis di dalam pembentukan karakter dan moral masyarakat, karena dalam agama individu dituntut untuk melakukan berbagai kewajiban baik dia sebagai khalīfah di bumi maupun sebagai 'abdullāh. Hal ini terbukti dengan kedua statusnya tersebut manusia sebagai makhluk individu sekaligus sosial memiliki sekian kewajiban dan diharuskan oleh ajaran agama untuk menjaga kelestarian dan keseimbangan alam semesta. Karena pada dasarnya bangunan konstruksi masyarakat berada diatas elemen terkecil dari komunitas tersebut, 
yaitu indivdu; ketika seorang invidu baik maka bisa dijamin baiklah masyarakat dimana individu tersebut berada. []

\section{Daftar Pustaka}

El-Affendi, Abdel Wahab, Masyarakat tak Bernegara, Kritik Teori Politik Islam, Yogyakarta: LkiS, 2000.

Azhar, Muhammad, Filsafat Politik, Perbandingan antara Islam dan Barat, Jakarta: Rajawali Pers, 1997.

Bagus, Loren, Kamus Filsafat, Jakarta: Gramedia, 1996.

Bakker, Anton dan Zubair, Achmad Harris, Metodologi Penelitian Filasafat, Yogyakarta: Kanisius, 1990.

Budiman, Arief, Teori Negara: Negara, Kekuasaan dan Ideologi, Jakarta: Gramedia, 2002.

Cahyadi, Hari, Tim Redaksi Driyarkara, Diskursus Kemasyarakatan dan Kemanusiaan, Jakarta: Gramedia1993.

Driyarkara, Jurnal Filsafat, edisi Th. XXVI, No. 1, 2002.

Engineer, Asghar Ali, Islam dan Teologi Pembebasan, Yogyakarta: Pustaka Pelajar, 1999.

Fakhry, Majid, Sejarah Filsafat Islam, terj. Mulyadhi Kartanegara, Jakarta: Pustaka Jaya, 1987.

Hadiwijono, Sejarah Filsafat Barat, Yogyakarta: Kanisius, 1980.

Jacques, Jean, Du Contract Social, Perihal Kontrak Sosial, Jakarta: Dian Rakyat, 1989.

Kaelan, Metode Penelitian Kualitatif Bidang Filsafat, Yogyakarta: Paradigma, 2005.

__ Filsafat Bahasa: Masalah dan Perkembangannya, Yogyakarta: Paradigma, 2002.

Kattsof, Louis O., Pengantar Filsafat, Terj. Soejono Soemargono, Yogyakarta: Tiara Wacana, 1987.

Khaldun, Ibnu, Muqaddimah, terj. Ahmadie Thoha, Jakarta: Pustaka Firdaus, 2000.

Locke, John, Kuasa Itu Milik Rakyat, Essai Mengenai Asal Mula Sesungguhnya, Ruang Lingkup dan Maksud Tujuan Pemerintahan Sipil, Yogyakarta: Kanisius, 2000. 
Machendrawaty, Nanih dan Safe'i, Agus Ahmad, Pengembangan Masyarakat Islam, Dari Ideologi, Strategi sampai tradisi, Bandung: Rosda, 2001.

Al-Mawardi, Al-Ahkām As-Sulțaniyyah, Prinsip-prinsip Penyelenggaraan Negara Islam, Jakarta: Darul Falah, 2000.

, Kenikmatan Kehidupan Dunia dan Agama: Etika dalam Pergaulan, Jakarta: Pustaka Azzam, 2001.

Patah, Akhmad, "Adāb Al-Dunyā Wa al-Dīn, Aspek Pendidikan", Tesis, Pasca sarjana IAIN Sunan Kalijaga: Yogyakarta, 1997.

Paul, Johnson Doyle, Teori Sosiologi Klasik dan Modern jilid 1, Jakarta: Gramedia, 1994.

Ruswantoro, Alim, Pengantar Filsafat Sosial, sebuah pengantar kuliah, Magelang: Tp, 2001.

Schmandt, Henry J., Filsafat Politik; Kajian Historis dari Zaman Yunani Kuno sampai Zaman Modern, Yogyakarta: Pustaka Pelajar, 2002.

Sjadzali, Munawir, Islam dan Tatanegara;Ajaran, Sejarah dan Pemikiran, Jakarta: UI Press, 1993.

Suseno, Franz Magnis, Fisafat Sebagai Ilmu Kritis, Yogyakarta: Kanisius, 1992.

Titus, Horald H., Dkk. Persoalan-Persoalan Filsafat, Jakarta: Bulan Bintang, 1984.

Veeger, K.J., Realitas Sosial, Jakarta: Gramedia, 1993.

Woodhouse, Mark B., Berfilsafat: sebuah Langkah Awal, Yogyakarta: Kanisius, 2000. 